\title{
Contextual Factors and Administrative Changes
}

\author{
Davood Askarany \\ University of Canberra, \\ Canberra, Australia
}

daskarany@hotmail.com

\author{
Malcolm Smith \\ University of South Australia \\ Adelaide, Australia
}

malcolm.smith@unisa.edu.au

\begin{abstract}
This paper explores the impact of a variety of contextual factors on the diffusion of six administrative innovations. The paper explores the level importance of 13 contextual factors on decisions(s) to implement (or not) administrative changes. It also examines the level of association between contextual factors and the diffusion of six administrative innovations, finding that the several contextual factors contribute significantly to the incidence of administrative change.
\end{abstract}

Key words: Contextual factors; administrative changes; diffusion; innovation

\section{Introduction}

During the past two decades, the world has witnessed a technological evolution that has provided a totally new environment for organisations. It has also been argued that the growing level of global competition leads to the adoption of such technological evolution, which may require the adoption of complementary administrative innovation (e.g., Baines \& Langfield-Smith 2003). However, studies investigating the diffusion of innovations suggest that administrative innovations lag behind technological innovations (e.g., Chenhall, 2003; Gosselin, 1997).

To facilitate the diffusion of administrative innovations, studies addressing the diffusion of administrative changes suggest further investigation into the level of association between the diffusion of administrative changes and contextual factors (e.g., Chenhall, 2003; Chenhall \& Langfield-Smith, 1998; Gosselin, 1997; Lukka \& Shields, 1999; Szychta, 2002; Williams \& Seaman, 2001). The above provide the motivation for this paper to explore the level importance of contextual factors on decisions(s) to implement (or not) administrative changes, and to examine the level of association between contextual factors and the diffusion of six administrative innovations.

\section{Literature Review and Hypotheses Development}

For nearly two decades the literature has argued that administrative changes lag behind technological changes and therefore cannot cope with the requirement of current technological evolution

Material published as part of this journal, either on-line or in print, is copyrighted by Informing Science. Permission to make digital or paper copy of part or all of these works for personal or classroom use is granted without fee provided that the copies are not made or distributed for profit or commercial advantage AND that copies 1) bear this notice in full and 2) give the full citation on the first page. It is permissible to abstract these works so long as credit is given. To copy in all other cases or to republish or to post on a server or to redistribute to lists requires specific permission from the publisher at Publisher@InformingScience.org
(Innes \& Mitchell, 1991; Johnson \& Kaplan, 1987; Johnson, 1992, 1993). Unsurprisingly, therefore, there has been a growing interest into the study of the diffusion of administrative changes during the past two decades (e.g., Anderson, 1995; Askarany \& Smith $_{\mathrm{a}}, 2001 \mathrm{a}$; Baines \& LangfieldSmith, 2003; Booth \& Giacobbe, 
1998; Cavalluzzo \& Ittner, 2003; Chenhall, 2003; Chenhall \& Langfield-Smith, 1998; Gosselin, 1997; Guilding \& McManus, 2002; Maiga \& Jacobs, 2003; Malmi, 1999; Martinez \& Labeaga, 2002; Williams \& Seaman, 2001; Yao, Xu, Liu, \& Lu, 2003).

However, despite the contribution of these studies, recent survey evidence suggests that the level of adoption of recently developed administrative techniques is lower than those of traditional ones (Baines \& Langfield-Smith, 2003; Chenhall \& Langfield-Smith, 1998).

Classifying accounting innovations as 'administrative', Gosselin (1997, p.109) supports the argument that "administrative innovations tend to lag behind technical innovations because they are perceived by management as being less closely associated with the profit objectives of manufacturing organisations". Rogers (1995) states that most of the studies on innovation have been devoted to technological innovations rather than administrative ones. Undertaking a historical review of empirical and contingency-based research over the last two decades, Chenhall (2003) observes that there has been very little published contingency work on administrative innovations such as target costing, balanced scorecard and life cycle costing.

Chenhall \& Langfield-Smith (1998, p. 1) provide confirmation that administrative innovations tend to lag behind technical innovations, in a survey of Australian manufacturing firms. They find that "overall, the rates of adoption of traditional management accounting practice were higher than recently developed techniques", also noting that even though the evidence from their survey indicated an increase in the application of new cost and management accounting techniques, the level of adoption of most of these new techniques was relatively low compared with the other techniques surveyed. They note that the three most popular 'new' adoptions are of traditional methods: budgeting for planning financial position; capital budgeting; and performance evaluation using return on investment. Confirming previous studies, the findings of Askarany \& Smith (2000) indicate that the extent of administrative changes in the Australian Plastics Industry over a ten-year period (1986-1996) had been slower than those of technological changes.

Given the above several studies suggest a variety of contextual factors (such as organisational culture, institutional pressure, employee awareness of the benefits of an innovation, a recognized need for change, the degree of uncertainty associated with the outcomes of the innovation) which may impact the diffusion of administrative innovations (e.g., Anderson \& Young, 1999; Askarany \& Smith $_{\mathrm{b}}$, 2001b; Baines \& Langfield-Smith, 2003; Booth \& Giacobbe, 1998; Cavalluzzo \& Ittner, 2003; Chenhall, 2003; Chenhall \& Langfield-Smith, 1998; Gosselin, 1997; Guilding \& McManus, 2002; Maiga \& Jacobs, 2003; Malmi, 1999; Martinez \& Labeaga, 2002; Williams \& Seaman, 2001; Yao, Xu, Liu, \& Lu, 2003). In line with the above literature, therefore, the following hypotheses are proposed:

$\mathbf{H}_{1} \quad$ Contextual factors are significantly important in decisions to adopt (or not) administrative innovations.

$\mathbf{H}_{2}$ Diffusion of administrative innovations is significantly associated with contextual factors addressed in this study.

The remainder of this paper is organised as follows: The research method and the development of the survey is explained in Section 3. Section 4 contains survey findings and hypothesis testing, and Section 5 a discussion of the limitations of the survey together with conclusions.

\section{Research Method}

In order to achieve an Australia-wide sample, this study used a cross-sectional mail survey of all management accountants who were CPA members and employed with industries registered with CPA Australia. CPA is the largest professional accounting body in Australia with the majority of 
its members involved with cost and management accounting in commerce and industry (in small and large firms), making it an appropriate source of a sample for this study. Identifying the targeted sample, CPA provided the authors with the names and addresses of all 755 management accountants registered with CPA, and designated within the database as performing management accounting functions. The survey conducted in the latter part of 2001, targeted all 755 management accountants thus identified by CPA. However, a closer examination revealed that only 501 members were employed and involved with management accounting tasks in Australian firms (including: building and construction, energy, engineering, healthcare, metals, mining and extraction, paper and packaging, retail, distribution and transport) at the time of the survey. These 501 members were targeted respondents for the survey.

Reviewing the diffusion literature and undertaking a survey study, Askarany and $\operatorname{Smith}_{\mathrm{b}}(2001 \mathrm{a})$ list a variety of contextual factors (addressed in the literature) including attributes of innovation and other contextual factors. Among contextual factors addressed in the literature (reported by Askarany and Smith) there are 13 factors which have been cited more frequently than other contextual factors (e.g., Björnenak \& Olson, 1999; Damanpour and Gopalakrishnan, 1998; Gosselin, 1997; Hoffman, 1999; Libby and Waterhouse, 1996) and been chosen in this study as follows.

1. Employee awareness of the benefits of an innovation

2. Employee awareness of the ready availability of an innovation

3. Cost of implementation and maintenance of the innovation

4. Dissatisfaction with the current system

5. Institutional pressures for innovation

6. Lack of confidence in the ability of innovation

7. A recognised need for change

8. The degree of uncertainty associated with the outcomes of the innovation

9. The amount of investment needed for an innovation on its implementation

10. The time involved to implement the new techniques(s)

11. Clear commitment from senior management towards the project

12. The existence of a widely recognised 'champion' of the implementation

13. The employment of management consultants to facilitate implementation

Following the identification of contextual factors, the next task was to identify a proxy for administrative innovations. Undertaking a historical review of empirical and contingency-based research over the last two decades, Chenhall (2003) classifies all recently developed management accounting innovations as administrative changes. Consistent with Barbera, Baxter \& Birkett (1999), Bjornenak \& Olson (1999), Chenhall \& Langfield-Smith (1998) and Lukka \& Shields (1999), an extensive literature review and a three-year survey of professional and practitioner journals, conferences and workshops in Australia, revealed the six most popular recently developed cost and management accounting innovations (as a proxy for administrative changes) in Australia to be:

Activity based costing $(\boldsymbol{A B C})$ : An approach to costing that focuses on activities as the fundamental cost objects. It uses the cost of these activities as the basis for assigning costs to other cost objects such as products, services, or customers.

Activity based management (ABM): Use of $\mathrm{ABC}$ concepts to facilitate the identification and reduction of non-value-added activities. 
Balanced scorecard: An integrated strategic performance management framework that helps organisations translate strategic objectives into relevant performance measures, by linking nonfinancial measures with a financial perspective in four areas of performance concerned with: financials, internal process, customers and innovation \& learning.

Benchmarking: The search for industry best practice that will lead to superior performance. It emphasises an outward focus and seeks to improved performance by learning from the experience of effective organisations.

Strategic management accounting (SMA): A focus on the analysis of the external environment which mandates corrections and adjustments to the internal control systems structures and decision support systems which are vital for the survival of organisations. SMA has an orientation towards the organisation's environment such as suppliers, customers, and its competitive position relative to both existing and potential competitors.

Target costing: A form of costing system in which the manufacture of a product or the provision of a service is restricted within a predetermined total cost ceiling so that a competitive price is achieved.

Given the above, respondents to the survey of CPA members were asked to determine the level of importance of the influence of the listed contextual factors on their decision to implement cost and management accounting innovations based on the following scale:

1. Very important

2. Important

3. Neutral

4. Not very important

5. Irrelevant

Following Booth and Giacobbe (1998), the questionnaire also sought information on the level of the diffusion of six management accounting innovations as follows:

- Discussions have not taken place regarding the introduction of this practice

- A decision has been taken not to introduce this practice

- Some consideration is being given to the introduction of this practice

- This practice has been introduced on a trial basis

- This practice has been implemented and accepted

Pilot tests of the instrument were initially undertaken with a group of university academics, managers and management accountants. Before the survey instrument was mailed to the organisations under investigation, its content validity was addressed by asking a group of management accounting lecturers and postgraduate students with manufacturing experience to review the instrument for clarity and meaning and to refine the design and focus of the content further. Modifications were made as deemed necessary. To help motivate response, respondents were offered a final report of the results together with the resulting recommendations to improve the diffusion of cost and management accounting innovations. Non-response bias was studied, comparing the information provided by the early respondents and the late respondents. There was no perceived difference between the responses of the early and late respondents, suggesting that non-response bias would not influence the outcomes significantly. 


\section{Survey Findings and Hypotheses Testing}

Responses to the survey were provided by 100 questionnaires, representing a response rate of $20 \%$. Non-response bias was examined through a comparison between early and late responses in terms of number of employees and the level of the diffusion of all six management accounting innovations. The findings indicated that there was no meaningful difference between early and late responses nor between industries, suggesting that non-response bias would not influence the outcomes. Using the results of the study, this paper examines the relationship between contextual factors and the diffusion of administrative innovations through tests of the stated hypotheses.

\section{Contextual Factors}

Answers to questions on contextual factors were provided by asking respondents in a direct question to identify the level of importance of the influence of a list of 13 contextual factors on their decision to implement a cost and management accounting innovation based on the following scale: very important $=1$; important $=2$; neutral $=3$; not very important $=4$; irrelevant $=5$. This scale permits the calculation of mean and standard deviation scores for each factor and the conduct of regression analysis and t-tests (Emory \& Cooper, 1991).

Table 1 reports on the extent to which respondents agree or disagree that the decision to implement cost and management accounting innovations (administrative changes) would be influenced by these contextual factors.

Table 1: t-Tests regarding the significance of importance of contextual factors on the diffusion of administrative changes

\begin{tabular}{|l|l|l|l|l|}
\hline \multicolumn{1}{|c|}{ Contextual factors } & Mean & $\begin{array}{c}\text { Std. } \\
\text { Dv. }\end{array}$ & \multicolumn{1}{|c|}{$\begin{array}{c}\text { Sig. } \\
\mathbf{( 2 -} \\
\text { tailed) }\end{array}$} \\
\hline Employee awareness of the benefits of an innovation & 3.52 & 1.020 & 5.099 &. $\mathbf{0 0 0}$ \\
\hline Employee awareness of the ready availability of an innovation & 3.18 & .936 & 1.923 &. $\mathbf{0 5 7}$ \\
\hline Cost of implementation and maintenance of the innovation & 4.13 & .895 & 12.625 &. $\mathbf{0 0 0}$ \\
\hline Dissatisfaction with the current system & 3.80 & .943 & 8.485 &. $\mathbf{0 0 0}$ \\
\hline Institutional pressures for innovation & 2.87 & .939 & -1.384 & .169 \\
\hline $\begin{array}{l}\text { Lack of confidence in the ability of new cost and management account- } \\
\text { ing technique to match requirements }\end{array}$ & 3.45 & .947 & 4.753 &. $\mathbf{0 0 0}$ \\
\hline A recognised need for change & 3.86 & .841 & 10.225 &. $\mathbf{0 0 0}$ \\
\hline The amount of investment required to adopt the innovation & 3.75 & .956 & 9.45 &. $\mathbf{0 0 0}$ \\
\hline The degree of uncertainty associated with the outcomes of the innovation & 3.51 & .859 & 5.940 &. $\mathbf{0 0 0}$ \\
\hline The time involved to implement the new techniques(s) & 3.46 & 1.039 & 4.428 &. $\mathbf{0 0 0}$ \\
\hline Clear commitment from senior management towards the project & 4.49 & .703 & 21.181 &. $\mathbf{0 0 0}$ \\
\hline The existence of a widely recognised 'champion' of the implementation & 3.78 & .938 & 8.313 &. $\mathbf{0 0 0}$ \\
\hline The employment of management consultants to facilitate implementation & 2.73 & 1.004 & -2.690 &. $\mathbf{0 0 8}$ \\
\hline
\end{tabular}

According to Table 1, except for the factor named 'institutional pressures for innovation' with a mean value of 2.87 (close to mean value of 3 as neutral), the mean values of all other 12 influenc- 
ing factors are significantly (significant at $\mathrm{p}<0.000$ to $\mathrm{p}<0.094$ ) inclined towards 'agree' and 'strongly agree'. The findings suggest that the decision to implement (or not) any administrative innovation is significantly influenced by the other 12 influencing factors addressed in this study. So, we cannot reject our first stated hypothesis $\left(\mathrm{H}_{1}\right)$, concluding that the specified contextual factors significantly influence the decision(s) to implement (or not) administrative changes. The only factor at variance with this outcome is the 'influence of institutional pressures on implementation of an innovation' (at the 5\% level of significance).

\section{Administrative Changes}

Table 2 details the diffusion stages of six recently management accounting innovations as a proxy for administrative changes in the targeted population.

Table 2: The diffusion stages of management accounting techniques

\begin{tabular}{|l|c|c|c|c|c|c|}
\hline $\begin{array}{c}\text { Management ac- } \\
\text { counting techniques }\end{array}$ & $\begin{array}{c}\text { No dis- } \\
\text { cussion }\end{array}$ & $\begin{array}{c}\text { Decided } \\
\text { not to } \\
\text { introduce }\end{array}$ & $\begin{array}{c}\text { Some consid- } \\
\text { eration is } \\
\text { given }\end{array}$ & $\begin{array}{c}\text { Introduced } \\
\text { on trial basis }\end{array}$ & $\begin{array}{c}\text { Imple- } \\
\text { mented and } \\
\text { accepted }\end{array}$ & Total \\
\hline Activity based costing & 38 & 13 & 21 & 9 & 19 & 100 \\
\hline $\begin{array}{l}\text { Activity based man- } \\
\text { agement }\end{array}$ & 54 & 9 & 17 & 9 & 11 & 100 \\
\hline Balanced scorecard & 36 & 4 & 16 & 21 & 23 & 100 \\
\hline Benchmarking & 25 & 3 & 20 & 17 & 35 & 100 \\
\hline $\begin{array}{l}\text { Strategic Management } \\
\text { Accounting }\end{array}$ & 53 & 4 & 13 & 17 & 13 & 100 \\
\hline Target costing & 53 & 5 & 13 & 13 & 16 & 100 \\
\hline
\end{tabular}

Given that six management accounting innovations (addressed in this study) are used as a proxy for administrative change, Tables 3 reports the details of the analysis of scale reliability and unidimensionality for such innovations. The six-item measure achieved an alpha value of 0.6406 (Cronbach, 1951) and a standardized item alpha of 0.6407. This figure is marginally below the value of 0.70 recommended by Nunnally (1978, p.245), but can be regarded as moderate (Brownell and Dunk, 1991, p.697) and acceptable (Daft and Macintosh, 1981, p.214). Table 3 also shows the total-item correlations for each of the scale composites, with ranges from 0.3280 to 0.4184 . According to De Vaus (1991, p.239), values above 0.30 generally indicate acceptable scale undimensionality.

Table 3: Analysis of scale reliability and undimensionality: management accounting innovations

\begin{tabular}{|l|c|c|c|c|c|}
\hline $\begin{array}{c}\text { Management accounting } \\
\text { techniques }\end{array}$ & Cases & Mean & Std Dev & $\begin{array}{c}\text { Correlated Item- } \\
\text { Total Correlation }\end{array}$ & $\begin{array}{c}\text { Alpha if } \\
\text { item deleted }\end{array}$ \\
\hline Activity based costing & 100 & 2.5800 & 1.5320 & 0.3280 & 0.6129 \\
\hline Activity based management & 100 & 2.1400 & 1.4356 & 0.3609 & 0.6014 \\
\hline Balanced scorecard & 100 & 2.9600 & 1.6387 & 0.3632 & 0.6005 \\
\hline Benchmarking & 100 & 3.3900 & 1.5884 & 0.3601 & 0.6014 \\
\hline Strategic Management Ac- & 100 & 2.3800 & 1.5941 & 0.4184 & 0.5789 \\
\hline
\end{tabular}




\begin{tabular}{|l|l|l|l|l|l|}
\hline counting & & & & & \\
\hline Target costing & 100 & 2.3900 & 1.6261 & 0.3918 & 0.5892 \\
\hline
\end{tabular}

Both contextual factors and administrative innovations were tested for univariate normality using the Kolmogorov-Smirnov test and the tests of the indices of skewness and kurtosis. In all cases the assumption that the sample represents a normal population could not be rejected.

\section{Contextual Factors versus Administrative Changes}

The questionnaire sought information on the stages of diffusion of each of six recently developed cost and management accounting techniques in organisations: Activity-based costing (ABC), activity-based management (ABM), Balanced Scorecard, Benchmarking, Strategic Management Accounting (SMA) and Target Costing.

Given the number of variables (both for contextual factors and administrative changes), a Canonical Correlation approach is the most preferred method to examine the level of association between two groups of variables (Gebers \& Peck, 2003). Gebers \& Peck suggest that a Canonical Correlation approach improves both accuracy and the level of correlation simultaneously and reveals the best-existed association between dependent and independent variables. Supporting this view, Tett, Steele \& Beauregard (2003) point out that canonical correlations provide notable improvements in criterion validity over inter-factor correlations and help summarize the data while retaining the diagnostic advantages of specificity. Table 4 summarises the model examining the association between contextual factors and administrative changes.

Table 4: Regression model summary: Canonical Correlation

\begin{tabular}{|c|c|c|c|c|c|}
\hline Model & $\begin{array}{c}\text { Unstandard- } \\
\text { ized Coeffi- } \\
\text { cients }(B)\end{array}$ & Std. Error & $\begin{array}{c}\text { Standard- } \\
\text { ized Coeffi- } \\
\text { cients } \\
\text { (Beta) }\end{array}$ & $\mathbf{t}$ & Sig. \\
\hline (Constant) & 0.570 & 0.987 & & 0.578 & 0.565 \\
\hline $\begin{array}{l}\text { Influence of awareness of the benefits of innovation on } \\
\text { its implementation }\end{array}$ & 0.367 & 0.135 & 0.374 & 2.713 & 0.008 \\
\hline $\begin{array}{l}\text { Influence of awareness of the availability of innovation } \\
\text { on its implementation }\end{array}$ & 0.352 & 0.146 & 0.330 & -2.413 & 0.018 \\
\hline $\begin{array}{l}\text { Influence of the cost implementation of the innovation } \\
\text { on its implementation }\end{array}$ & $-9.843 \mathrm{E}-02$ & 0.135 & -0.088 & 0.728 & 0.468 \\
\hline $\begin{array}{l}\text { Influence of dissatisfaction with current system on } \\
\text { implementation of the innovation }\end{array}$ & $6.201 \mathrm{E}-02$ & 0.108 & 0.058 & -0.577 & 0.566 \\
\hline $\begin{array}{l}\text { Influence of institutional pressures on implementation } \\
\text { of an innovation }\end{array}$ & 0.135 & 0.114 & 0.126 & 1.185 & 0.239 \\
\hline $\begin{array}{l}\text { Influence of lack of confidence in the ability of new } \\
\text { technique on its implementation }\end{array}$ & -0.338 & 0.116 & -0.320 & -2.907 & 0.005 \\
\hline $\begin{array}{l}\text { Influence of the need for an innovation on its imple- } \\
\text { mentation }\end{array}$ & 0.163 & 0.120 & 0.137 & 1.361 & 0.177 \\
\hline $\begin{array}{l}\text { Influence of the amount of investment needed for an } \\
\text { innovation on its implementation }\end{array}$ & $2.864 \mathrm{E}-03$ & 0.131 & 0.003 & 0.022 & 0.983 \\
\hline
\end{tabular}




\begin{tabular}{|c|c|c|c|c|c|}
\hline $\begin{array}{l}\text { Influence of uncertainty associated with the outcomes } \\
\text { of an innovation on its implementation }\end{array}$ & -0.176 & 0.128 & -0.151 & 1.376 & 0.172 \\
\hline $\begin{array}{l}\text { Influence of the required time for implementation of an } \\
\text { innovation on its implementation }\end{array}$ & $3.848 \mathrm{E}-02$ & 0.103 & -0.040 & 0.373 & 0.710 \\
\hline $\begin{array}{l}\text { Influence of management commitment on implementa- } \\
\text { tion of an innovation }\end{array}$ & 0.327 & 0.138 & 0.230 & -2.370 & 0.020 \\
\hline $\begin{array}{l}\text { Influence of a widely recognised champion on imple- } \\
\text { mentation of an innovation }\end{array}$ & 0.123 & 0.108 & 0.116 & 1.141 & 0.257 \\
\hline $\begin{array}{l}\text { Influence of management consultants on implementa- } \\
\text { tion of an innovation }\end{array}$ & .0191 & 0.102 & 0.191 & -1.875 & 0.064 \\
\hline
\end{tabular}

The model reveals an $\mathrm{R}$ of 0.533 , an $\mathrm{R}^{2}$ of 0.284 and an adjusted $\mathrm{R}^{2}$ of 0.176 . Cohen (1988, p.412) suggests that all adjusted $R$-squares in excess of 0.02 should be considered as non-trivial. Thus, with this model more than $28 \%$ of the variation in the diffusion of administrative innovations is explained by contextual factors addressed in this study. The signs of all coefficients are all intuitively appropriate. Variance Inflation Factors (VIF) scores are all below two, indicating no serious problems with multicollinearity within the set of variables (Cavalluzzo and Ittner, 2003).

Analysis of variance for the model shows that there is a significant association between contextual factors and administrative changes $(\mathrm{F}=2.627$; $\mathrm{sig}=0.004)$. We cannot therefore reject our second hypothesis $\mathrm{H}_{2}$, that a relationship exists between contextual factors and administrative changes.

The results of the statistical analysis in this paper suggest that the diffusion of administrative changes is significantly associated (significant at 0.005 to 0.064 levels) with five contextual factors (out of 13 contextual factors addressed in the current study). According to the findings, administrative changes are positively associated with awareness of the benefits of innovation, awareness of the availability of innovation, management commitment on implementation of an innovation, management consultants on implementation of an innovation, and negatively associated with the lack of confidence in the ability of new technique.

\section{Conclusion and Limitations}

This study examined the level of importance of contextual factors on decisions(s) to implement (or not) administrative changes. It also examined the level of association between contextual factors and administrative changes. The results show that contextual factors are significantly influence decisions to adopt (or not) administrative innovations. The findings also suggest that the diffusion of administrative innovations is significantly associated with the specified contextual factors addressed in this study.

The findings of this study suggest that five contextual factors: awareness of the benefits of innovation, awareness of the availability of innovation, management commitment on implementation of an innovation, management consultants on implementation of an innovation, and confidence in the ability of the new technique are fundamental to the decision to adopt administrative changes. Further study is recommended to investigate the impact of other contextual factors on the diffusion of administrative changes.

The findings, conclusions and the implications in this study should be interpreted based on the normal limitations of mail surveys, such as lack of researcher interaction with respondents and follow up interviews. This is especially so given the relatively low response rate of $20 \%$, though 
associated tests for non-response bias yielded satisfactory outcomes. The useable response rate of $20 \%$ is clearly lower than anticipated. However, such a rate is sufficient to undertake the statistical analyses, though caution should be exercised for generalizing such analyses.

\section{References}

Anderson, S. W. (1995). A framework of assessing cost management system changes: The case of activity based costing implementation at General Motors, 1986-1993. Journal of Management Accounting Research, Fall 7, 1-51.

Anderson, S. W., \& Young, S. M. (1999). The impact of contextual and process factors on the evaluation of activity-based costing systems. Accounting, Organizations and Society, 24, 525-559.

Askarany, D., \& Smith, M. (2000). The impact of contextual factors on the diffusion of accounting innovation: Australian evidence. Sixth Interdisciplinary Perspectives on Accounting Conference, (IPA), July, Manchester, UK.

Askarany, D., \& Smith, M. (2001a). Diffusion of cost and management accounting innovations: Generation or adoption? Proceedings of the Information Resources Management Association, (IRMA), May, Toronto Canada.

Askarany, D., \& Smith, M. (2001b). Facilitating accounting changes in the global environment. Economies and Business in Transition, July, Istanbul.

Baines, A., \& Langfield-Smith, K. (2003). Antecedents to management accounting change: a structural equeation approach. Accounting Organizations and Society, 28 (7-8), 657-698.

Barbera, M., Baxter, J., \& Birkett, W. (1999). Innovation management accounting practices- Insights from practice. Sydney: UNSW Press.

Björnenak, T., \& Olson, O. (1999). Unbundling management accounting innovations. Management Accounting Research, 10, 325-338.

Booth, P., \& Giacobbe, F. (1998). The impact of demand and supply factors in the diffusion of accounting innovations: The adoption of activity-based costing in Australian manufacturing firms. Management Accounting Conference, September, Sydney.

Brownell, P., \& Dunk, A. S. (1991). Task uncertainty and its interaction with budgetary participation and budget emphasis: Some methodological issues and empirical investigation. Accounting, Organizations and Society, 6 (8), 693-703.

Cavalluzzo, K. S., \& Ittner, C. D. (2003). Implementing performance measurement innovations: Evidence from government. Accounting Organizations and Society, (In Press).

Chenhall, R. H. (2003). Management control systems design within its organisational context: Findings from contingency-based research and direction for the future. Accounting, Organizations and Society, $28,127-168$.

Chenhall, R. H., \& Langfield-Smith, K. (1998). Adoption and benefits of management accounting practices: An Australian study. Management Accounting Research, 9, 1-19.

Cohen, J. (1988). Statistical power analysis for behavioural sciences (2nd ed.). Hillsdale: Lawerence Erlbaum Associates.

Cronbach, L. J. (1951). Coefficient alpha and the internal structure of tests. Psychometrika, 16, 3, 297-334.

Daft, R. L., \& Mclntosh, N. B. (1981). A tentative exploration into the amount of equvivocality of information processing in organisational work units. Administrative Science Quarterly, 26, 207-224.

Damanpour, F., \& Gopalakrishnan, S. (1998). Theories of organizational structure and innovation adoption: the role of environmental change. Journal of Engineering and Technology Management, JETM, 15, 124. 
De Vaus, D. A. (1991). Survey in social research (3rd ed.). Sydney: Allen \& Unwin.

Emory, C. W. \& Cooper, D. R. (1991). Business research methods. Boston: Irwin.

Gebers, M. A., \& Peck, R. C. (2003). Using traffic conviction correlates to identify high accident-risk drivers. Accident Analysis \& Prevention, 35, 6, 903-913.

Gosselin, M. (1997). The effect of strategy and organisational structure on the adoption and implementation of activity based costing. Accounting, Organizations and Society, 22 (2), 105-122.

Guilding, C., \& McManus, L. (2002). The incidence, perceived merit and antecedents of customer accounting: an exploratory note. Accounting Organizations and Society, 27 (1-2), 45-59.

Innes, J., \& Mitchell, F. (1991). ABC: A survey of CIMA members. Management Accounting Research, 6, 137-153.

Johnson, H. T. (1992). Relevance regained. New York: The Free Press.

Johnson, H. T., \& Kaplan, R. S. (1987). Relevance lost. Harvard, USA: Harvard Business School Press.

Libby, T., \& Waterhouse, J. H. (1996). Predicting change in management accounting systems. Journal of Management Accounting Research, 8, 137-150.

Lukka, K., \& Shields, M. (1999). Innovations in management accounting focus. Management Accounting, 77, 3, 33-38. London.

Maiga, A. S., \& Jacobs, F. A. (2003). Balanced scorecard, activity-based costing and company performance: An empirical analysis. Journal of Management Issues, 15, 3, 283-301.

Malmi, T. (1999). Activity-based costing diffusion across organizations: An exploratory empirical analysis of Finnish firms. Accounting, Organizations and Society, 24, 649-672.

Martinez, R., E., \& Labeaga, J., M. (2002). The relationship between firm size and innovation activity: A double decision approach and an application to Spanish manufacturing firms. Economics of Innovation \& New Technology, 11, 1, 35-51.

Nunnally, J. C. (1978). Psychometric theory (2nd ed.). New York: McGraw-Hill.

Organisation for Economic Cooperation and Development (OECD). (1992). Technology and economy: The key relationship. OECD Paris.

Rogers, E. M. (1995). Diffusion of innovation (4th ed.). New York: Free Press.

Szychta, A. (2002). The scope and application of management accounting methods in Polish enterprises. Management Accounting Research, 13, 401-418.

Tett, R. P., Steele, J. R., \& Beauregard, R. S. (2003). Broad and narrow measures on both sides of the personality-job performance relationship. Journal of Organizational Behavior, 24 (3), 335-357.

Williams, J. J., \& Seaman, A. E. (2001). Management accounting systems change and departmental performance: The influence of managerial information and task uncertainty. Management Accounting Research, 13, 419-445.

Yao, J. E., Xu, X., Liu, C., \& Lu, J. (2003). Organisational size: a significant predictor of IT innovation adoption. Journal of Computer Information Systems, Winter, 76-82.

\section{Biographies}

Dr. Davood Askarany: BA, MA and Ph.D in management accounting, senior research associate and postdoctoral fellow.

Professor Malcolm Smith: Professor in School of Accounting and Information Systems. 